\title{
Equivalent Radiation Doses in Area of North Jordan
}

\author{
Nabil N. Al-Zubaidy ${ }^{1} \&$ Abdullah I. Mohammad ${ }^{2}$ \\ ${ }^{1}$ Department of Applied Science, Faculty of Engineering Technology, Al-Balqa Applied University, Amman, \\ Jordan, Amman, Jordan \\ ${ }^{2}$ Department of Basic Sciences, AL-Huson University College, AL-Balqa’ Applied University, Irbid, AL-Huson, \\ Jordan \\ Correspondence: Abdullah I. Mohammad, Department of Basic Sciences, AL-Huson University College, \\ AL-Balqa’ Applied University, Irbid, Jordan. Tel: 962-775-609-740. Emai: ab.ib_edu@yahoo.com
}

Received: April 12, 2012 Accepted: May 3, 2012 Online Published: July 16, 2012

doi:10.5539/apr.v4n3p70 URL: http://dx.doi.org/10.5539/apr.v4n3p70

\begin{abstract}
In this research the authors measured radon gas concentration inside Hakama homes and calculated equivalent radiation doses in the study area. The study started from 1 June 2011 to 1 September 2011. Study area was divided into four sectors (H East, H West, H North and H South). About 200 dosimeters containing highly pure CR-39 were distributed randomly among the houses of the different sectors. Two dosimeters were distributed in each house (first in the living room and the second in the guest room). The indoor dosimeters were collected after three months. The collected detectors were chemically etched using $30 \% \mathrm{KOH}$ for 8 hours at $70{ }^{\circ} \mathrm{C}$. An optical microscope was used to measure the nuclear alpha track density on the detectors surfaces.

The author found that the average radon concentration in the study area was ranged from $30.2 \mathrm{~Bq} / \mathrm{m}^{3}$ in the sector $\mathrm{H}_{\text {East }}$ to $25.7 \mathrm{~Bq} / \mathrm{m}^{3}$ in the sector $\mathrm{H}_{\text {South }}$. Moreover; the average radon concentration in the living rooms in the study area was $18.8 \mathrm{~Bq} / \mathrm{m}^{3}$ which is below that in the guest rooms $37 \mathrm{~Bq} / \mathrm{m}^{3}$.

Radon contributes in increasing of absorption radiation dose. The calculated equivalent radiation dose in the study area was 0.68 . The average radon concentration in the study area was below the Jordanian national level.
\end{abstract}

Keywords: radiation, radiation dose, equivalent doses, radon, houses radon, Jordan

\section{Introducation}

The effect of radiation depends on the amount of radiation we have received. Therefore, amounts of radiation received are referred to as doses, and the measurements of such doses are known as dosimetry.

The unit of absorbed dose is specified in terms of the amount of energy deposited by radiation in $1 \mathrm{~kg}$ of material. This unit is the Gray, abbreviated Gy. An absorbed radiation dose of 1 Gy corresponds to the deposition of 1 joule of energy in $1 \mathrm{~kg}$ of material. The gray is a measure of energy absorbed by $1 \mathrm{~kg}$ of any material, be it air, water, tissue or whatever. As we shall see for normal practical purpose we use the milligray (mGy) and the micro gray ( $\mu \mathrm{Gy})$. Absorbed dose is given the symbol $\mathrm{D}$.

Table 1. Relation between the type of radiation and the quality factor

\begin{tabular}{ccc}
\hline Radiation & Energy & Quality factor \\
\hline Gamma & All & 1 \\
Beta & All & 1 \\
Neutron & Slow & 5 \\
Neutron & Fast & 20 \\
Alpha & All & 20 \\
\hline
\end{tabular}

Studies have shown that alpha and neutron radiation cause greater biological damage for a given energy deposition per kg of tissue than gamma radiation dose (Field, Steck, \& Smith, 2000). In other words, equal doses of alpha and gamma radiation produce unequal biological effects. Because more biological damage is caused for 
the same physical dose, one gray of alpha radiation is more harmful than one gray of gamma radiation (UNSCEAR, 2000).

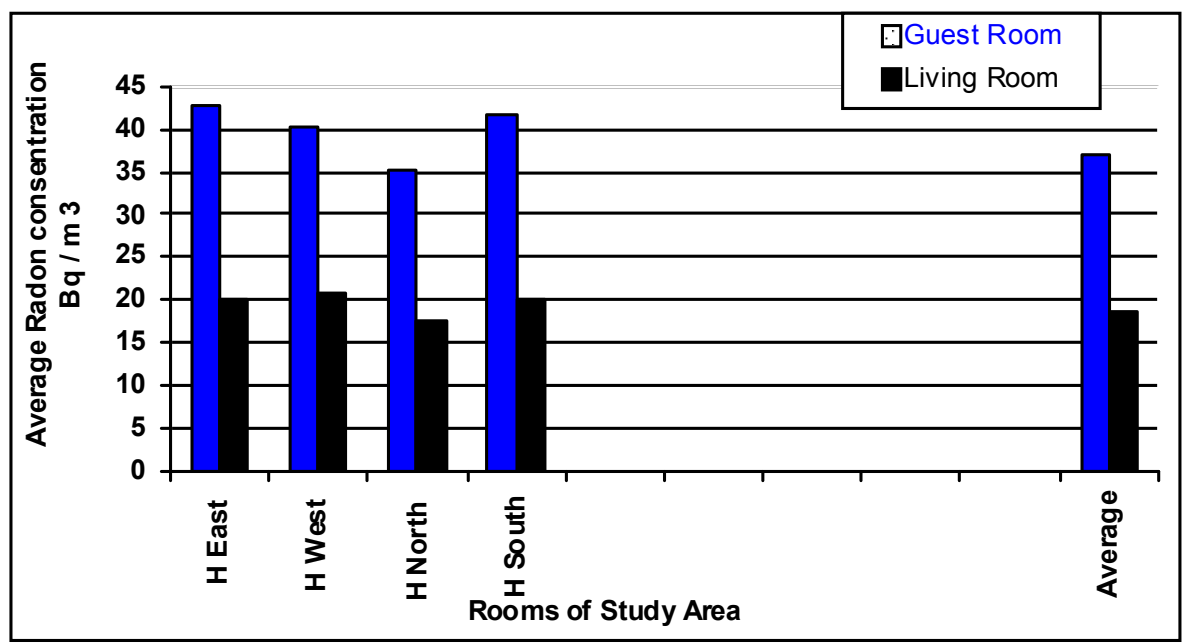

Figure 1. Average radon concentrations in different rooms in areas of study

Quality factors are used to compare the biological effects from different types of radiation. The quality factor of a radiation type is defined as the ratio of biological damage produced by the absorption of 1 Gy of that radiation to the biological damage produced by 1 Gy of X or gamma radiation (See Table 1).

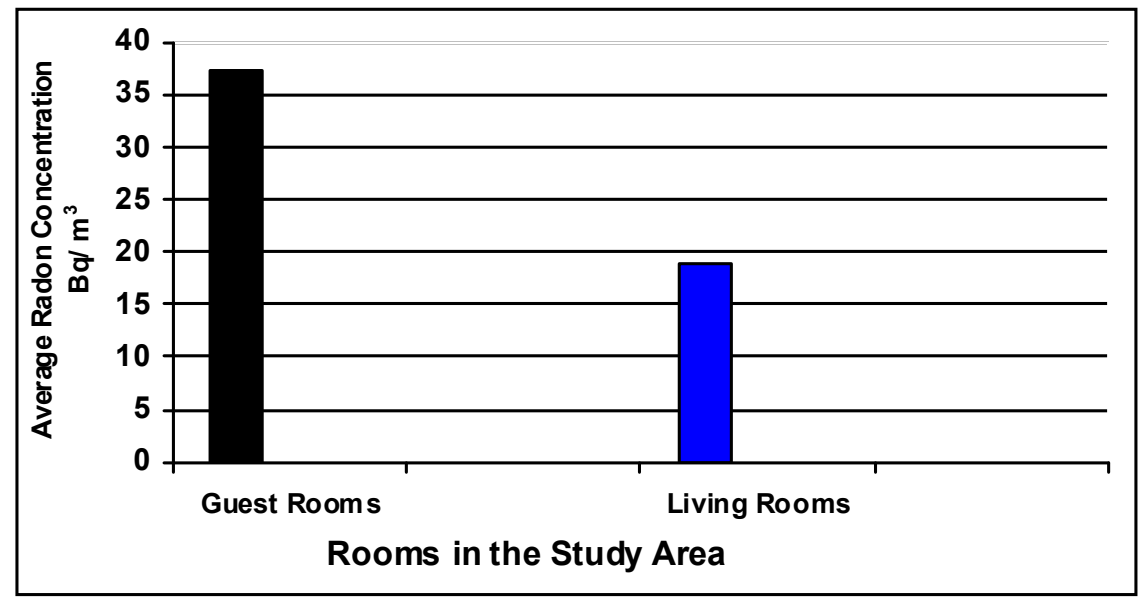

Figure 2. Relationship with the nature of radon concentration used rooms in the study area

The absorbed radiation dose, when multiplied by the quality factor of the radiation delivering the dose, will give us a measure of the biological effect of the dose. This is known as the equivalent dose $(\mathrm{H})$. The unit of $\mathrm{H}$ is the sievert (Sv). An equivalent dose of one sievert represents that quantity of radiation dose that is equivalent, in term of specified, we use the millisievert (mSv) and microsievert ( $\mu$ Sv) (UNSCEAR, 2006; UNSCEAR, 1998).

Equivalent dose, quality factor and absorbed dose are related by the expression:

$$
\mathrm{H}_{(\mathrm{Sv})}=\mathrm{D}_{(\mathrm{Gy})} \times \mathrm{Q}
$$

Where,

$\mathrm{D}$ : the absorbed dose in gray

$\mathrm{Q}$ : is the quality factor 


\section{$\mathrm{H}$ : the equivalent dose in sievert}

As we known, radon contributes in increasing of absorption radiation dose. The ICRP (1990) published in its report that each $1 \mathrm{~Bq} / \mathrm{m}^{3}$ of radon level means about $0.025 \mathrm{mSv} / \mathrm{y}$. so, to estimate the probability of getting lung cancer from radon concentration Cross (1992) found it equal $1.65 \times 10^{-2}$ if the radon concentration was 37 $\mathrm{Bq} / \mathrm{m}^{3}$.

This study aims to evaluate the levels of radon in Hakama city which lies $80 \mathrm{~km}$ north of Jordan. Measurements carried out using plastic detectors (CR-39), it is hoped that the study will pave for future surveys to establish a Jordanian map of radon emission levels in the different sites (Mohammad \& Abumurad, 2008; Khatibeh et al., 1997).The levels of radon in Hakama City were calculated to know Equivalent radiation Doses in the study area.

Table 2. Number of distributed, collected and lost dosimeters in the study area

\begin{tabular}{ccccc}
\hline Name & Distributed number & Collected number & Lost number & $\begin{array}{c}\text { Percentage for lost } \\
\text { dosimeter }\end{array}$ \\
\hline $\mathrm{H}_{\text {East }}$ & 50 & 40 & 10 & $20 \%$ \\
$\mathrm{H}_{\text {West }}$ & 60 & 56 & 4 & $6.7 \%$ \\
$\mathrm{H}_{\text {North }}$ & 40 & 38 & 2 & $5 \%$ \\
$\mathrm{H}_{\text {South }}$ & 50 & 42 & 8 & $16 \%$ \\
Total & 200 & 176 & 24 & $12 \%$ \\
\hline
\end{tabular}

\section{Measuring Procedures}

Hakama city was divided into four sectors from the center and coded $\mathrm{H}_{\text {East }}, \mathrm{H}_{\text {West }}, \mathrm{H}_{\text {North }}$ and $\mathrm{H}_{\text {South }}$. The division was based on the center of Hakama city to facilitate the distribution of the dosimeters which will be later collected and analyzed. An integrated passive radon dosimeter has been used for measurement of radon. The dosimeters contain solid state nuclear track detectors (CR-39) with dimension $\left(1.5 \times 1.5 \mathrm{~cm}^{2}\right)$. A detector fixed on the bottom of can use double face adhesive tape in each dosimeter, the dimensions of container $7.0 \mathrm{~cm}$ in diameter, $4.6 \mathrm{~cm}$ in depth. The container has been covered by lid and was made a circular hole of diameter 1.5 $\mathrm{cm}$ at the center of lid. The hole is covered by a piece of sponge with area of $\left(4 \mathrm{~cm}^{2}\right)$ and a thickness of $0.5 \mathrm{~cm}$, sealed on to the interior surface of lid (Abumurad, Al-Bataina, Ismail, Kullab, \& Al-Eloosy, 1997; Abumurad et al., 2001; Abumurad \& Al-Tamimi, 2005; Mohammad \& Abumurad, 2008; AL-Amairyeen, 2010; Nabil Al-Zubaidy \& Mohammad, 2011; Mohammad et al., 2012).

This configuration was made in order to allow the radon gas to pass through the sponge, while maintain the same calibration condition and to stop the aerosol and Thoron $\left({ }^{220} \mathrm{Rn}, \mathrm{t}_{1 / 2}=55.6 \mathrm{~s}\right)$ from entering the cup.

A bout 200 dosimeters were distributed in the study area (Hakama city). The study began in the June 1, 2011 and the ended in the September 1, 2011. The indoor dosimeters were collected after three months. The collected detectors were chemically etched using $30 \% \mathrm{KOH}$ for 8 hours at $70{ }^{\circ} \mathrm{C}$. An optical microscope was used to measure the nuclear alpha track density on the detectors surfaces.

The distribution in the four sectors was randomly (two dosimeter in every home), so put one in the guest room and the second in the living room were taken into account the number of floors in each sector (See Figure 2).

Table 3. Equivalent radiation doses in the study area

\begin{tabular}{|c|c|c|c|}
\hline Area name & $\begin{array}{l}\text { Average } \\
\left(\mathrm{Bq} / \mathrm{m}^{3}\right)\end{array}$ & concentration & Equivalent radiation doses \\
\hline $\mathrm{H}_{\text {East }}$ & 30.2 & & 0.76 \\
\hline $\mathrm{H}_{\text {West }}$ & 28 & & 0.7 \\
\hline $\mathrm{H}_{\text {North }}$ & 25.8 & & 0.65 \\
\hline $\mathrm{H}_{\text {South }}$ & 25.7 & & 0.643 \\
\hline
\end{tabular}




\section{Result and Discussions}

The author in this study found that the average concentration of radon in the guest rooms was $37 \pm 16.3 \mathrm{~Bq} / \mathrm{m}^{3}$, the largest concentrations of radon gas in the living rooms $18.8 \pm 5.5 \mathrm{~Bq} / \mathrm{m}^{3}$. We can explain it because the people who spend most of their time in living rooms and therefore tend to keep these rooms with proper ventilation so that they open the windows as well as the frequent use of fans in these rooms that the study coincided with the hot summer will operate the fan on the renewal of air room so less gas concentration of radon. The high concentration inside the guest rooms is due to the time spent by the population within them is very small so that it is almost non-existent reason is that these rooms are used only when the arrival of guests to the house, as well as the people do not do ventilate the room for fear on the furniture inside the rooms of dirt dust and dust (See Figure 1).

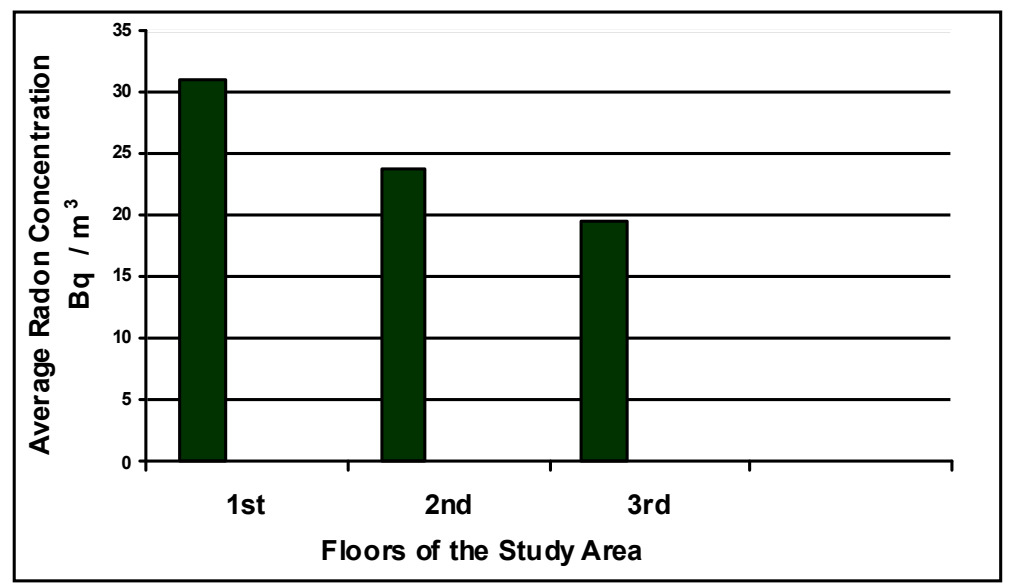

Figure 3. Relationship with the concentration of radon floors in the study area

Figure 3 shows that the average concentration in the first floor (ground) was $31.1 \pm 15.5 \mathrm{~Bq} / \mathrm{m}^{3}$ and in the second floor was $23.8 \pm 7.2 \mathrm{~Bq} / \mathrm{m}^{3}$ while the average concentration in the third floor was $19.6 \pm 7.5 \mathrm{~Bq} / \mathrm{m}^{3}$. We note the high concentration in the first floor due to near the floor from the soil, which is a major source of radon. It is also noticeable decline in concentration in the homes of the second floor and the third compared with the first reason was that the rate of radon emission at least as we head to the top. Also we noted the decrease in concentration of radon gas when we rise to the top of the floors in all areas without exception. The reason for this is that the density of radon greater than the density of air, as well as the potential for release of radon from the earth's crust at the bottom of the building, as well as that ventilate the upper floors are the best ventilation of basements in general.

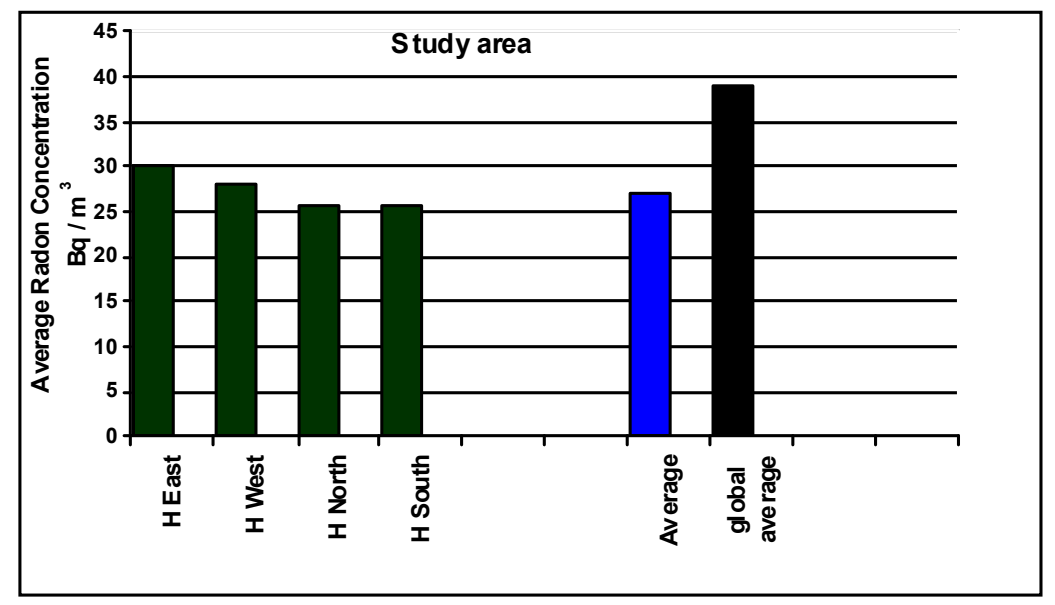

Figure 4. Compared to concentration of radon in houses of study areas with the global average and the average concentration in the city 
Through Figure 4, we note that the concentration of radon in sector $\mathrm{H}$ East was the largest and then the sector $\mathrm{H}$ West, and despite the fact that this region is high but the houses of this area was modern and there are some houses of the area gardens allow infiltration of radon from the soil of these gardens into the homes, In addition to the thickness of the soil in some places in this region is small and the layer of sedimentary rock may contain uranium, which contributes to increasing the concentration of radon in the soil and thus increase in the air of homes ( See Figure 4). Also we see that the average global concentration of radon in the air of homes $39 \mathrm{~Bq} / \mathrm{m}^{3}$ was higher than the average concentration in the study area $27.0 \mathrm{~Bq} / \mathrm{m}^{3}$ (See Figure 4). As we known, radon contributes in increasing of absorption radiation dose. The ICRP (1990) published in its report that each $1 \mathrm{~Bq} / \mathrm{m}^{3}$ of radon level means about $0.025 \mathrm{mSv} / \mathrm{y}$. the calculated equivalent radiation doses in the study areas was 0.68 (See Table 3 ).

\section{Conclusions}

The average radon concentrations in $\mathrm{H}_{\text {East }}, \mathrm{H}_{\text {west }}, \mathrm{H}_{\text {North }}$ and $\mathrm{H}_{\text {South }}$ areas were 30.2, 28, 25.8 and $25.7 \mathrm{~Bq} / \mathrm{m}^{3}$, respectively. The average radon concentration in the study area (north of Jordan) was $27 \mathrm{~B} / \mathrm{m}^{3}$. However, there were no clear appreciable differences between radon concentrations in all areas in the study area. The average radon concentration in the study area was below the recommended action level of ICRP (1990) and below to the Jordanian national level (Khatibeh et al., 1997; Mohammad \&Abumurad, 2008; Mohammad et al., 2012).

Radon contributes in increasing of absorption radiation dose. The ICRP (1990) published in its report that each 1 $\mathrm{Bq} / \mathrm{m}^{3}$ of radon level means about $0.025 \mathrm{mSv} / \mathrm{y}$. the calculated equivalent radiation doses in the study areas was 0.68 .

\section{References}

Abdullah, Mohammad. (2012). A study of natural radioactivity in dwellings of Umm Qais area using of the solid state nuclear tracks detectors (SSNTD'S). Adv. Theo. Appl. Mech, 5(2), 53-59.

Abumurad, K. (2001). Chances of lung cancer due to radon exposure in Al-Mazar Al-Shamali, Jordan. Radiat. Meas., 34, 537-540. http://dx.doi.org/10.1016/S1350-4487(01)00223-2

Abumurad, K., \& Al-Tamimi., M. (2005). Natural radioactivity due to radon in Soum region. Jordan. Radiat. Meas., 39, 77-80. http://dx.doi.org/10.1016/j.radmeas.2004.02.017

Abumurad, K., Al-Bataina, B., Ismail, A., Kullab, M., \& Al-Eloosy A. (1997). A Survey of Radon Levels in Jordanian Dwellings during an Autumn Season. Radiation Protection Dosimetry, 69(3), 221-226. http://dx.doi.org/10.1093/oxfordjournals.rpd.a031908

AL-Amairyeen, H. (2010). Radiation doses due to natural radioactivity in Wadi Bin Hammad, AlKarak, Jordan. International Journal of the Physical Sciences, 5(9), 1486-1488.

Annals of the ICRP (1990). Recommendations of the International Commission on Radiological Protection. Oxford: Pergamon Press.

Cross, F, T. (1992). Ed. Indoor Radon and Lung Cancer: Reality or Myth. Twenty-ninth Hanford Symposium on Heath and the Environment. Columbus: Batelle Press, 27-29.

Field, N., Steck, R., \& Smith, C. (2000). Residential radon gas exposure and lung cancer: the lowa Radon Lung Cancer Study. American of Epidemiology, 1091-1102. http://dx.doi.org/10.1093/oxfordjournals.aje.a010153

Khataibeh, A., Ahmad, N., Conway, M., Abumurad, K., Kullab, M., \& Al-Bataina, B. (1997). Measurement of indoor radon concentration levels in some cities of Jordan. Radiat. Meas., 28(1-6), 589-590.

Mohammad, A., \& Abumurad, K. (2008). Evaluation of radon gas concentration in the air of soil and dwellings of Hawar and Foara villages, using (CR-39) detectors. Radiat. Meas., 43, 452-455. http://dx.doi.org/10.1016/j.radmeas.2008.04.074

Nabil Al-Zubaidy, \& Abdullah Mohammad. (2011). Measurements of Radon Gas Concentrations in Hubras and Harta Villages and Its Effect on Public Health by Application of Nuclear Track Detectors (NTD's). European Journal of Scientific Research, 66(3), 404-407.

UNSCEAR. (1998). Sources, Effects and Risks of Ionizing Radiation United Nations. New York.

UNSCEAR. (2000). Sources and Effects of Ionizing Radiation, Report to the general Assembly. New York, United Nations.

UNSCEAR. (2006). Effects and Risks of Ionizing Radiations. New York, United Nations. 